\title{
WAWASAN HADIS TENTANG ETOS KERJA
}

\section{Muhammad Ali}

Prodi Ilmu Hadis Fakultas Ushuluddin Filsafat dan Politik

UIN Alauddin Makassar

E-mail: alingampo05@gmail.com

\section{Abstrak}

Terdapat 6 hadis tentang etos kerja yaitu; 1) hadis tentang niat, 2) hadis tentang bekerja dengan mencari kayu bakar, 3) hadis tentang tangan di atas lebih baik daripada tangan di bawa, 4) hadis tentang do'a meminta perlindungan dari kefakiran, 5) hadis tentang makanan yang paling baik adalah hasil dari kerja keras dan 6) hadis tentang menanam pohon sekalipun hari kiamat telah terjadi. Hadis-hadis tentang etos kerja tersebut terbagi ke dalam 3 aspek; 1) etos kerja dari aspek akidah, 2) etos kerja dari aspek ibadah dan 3) etos kerja dari aspek akhlak. Selanjutnya aplikasi hadis-hadis etos kerja pada masa kini ialah orang mukmin dalam bekerja harus memiliki niat yang kuat, jujur, istiqamah, amanah, tekun, kemampuan bekerja kerasa dan bertanggungjawab.

Kata Kunci: Fikih - Gender - nikah siri - Pencatatan nikah

\section{Pendahuluan.}

Dunia kerja merupakan persoalan yang banyak diperbincangkan orang dan dihubungkan pada dunia keagamaan, khususnya agama Islam di Indonesia. Dalam berbagai macam catatan, banyak laporan internasional mengenai kecenderungan kawasan Pasifik masa depan (the pacific rise). Pada satu sisi, orang percaya the pasific rise, terutama kawasan Pasifik Barat akan menjadi sentral peradaban di masa depan. Indonesia sempat menjadi salah satu nominasi the pasific rise, namun saat ini sudah mulai 
menyangsikan Indonesia akan bisa masuk klub the rising economy di masa depan. ${ }^{1}$

Salah satu kritik yang sering dialamatkan kepada Indonesia adalah persoalan lemahnya etos kerja dan kecenderungan merajalelanya korupsi. Hal ini menjadi suatu pertanyaan besar disebabkan ada kaitan antara religiusitas dan etos kerja seperti yang disinyalir oleh Max Webber bahwa Islam tidak memiliki prasyarat kerohanian untuk bisa muncul sebagai peradaban besar atau Islam menurut Max Webber, karena irasionalitas dan feodalismenya, maka ia tidak sesuai dengan cita-cita masyarakat dan etos kerja industrial. Hal ini dapat menjadi bahan pertimbangan, apalagi Indonesia adalah tempat mayoritas orang Islam. ${ }^{2}$

Dalam konteks kekinian, umat Islam di Indonesia telah masuk ke dalam lingkungan kerja industrial. Bahkan dikalkulasikan, di Indonesia banyak orang Islam yang menjadi pekerja di sektor-sektor industri tersebut. ${ }^{3}$ Namun, indeks-indeks produktifitas dan daya saing masyarakat mengalami penurunan yang luar biasa, sehingga pertanyaannya terkait dengan masyarakat Indonesia memang tidak mempunyai prasyarat etos kerja yang baik. Bila, dicermati konsepsikonsepsi awal agama Islam, seperti yang diakui Robert N. Bellah seorang sosiolog agama, Islam adalah suatu agama yang mendorong etos kerja yang luas biasa. ${ }^{4}$ Banyak diktum teks-teks agama yang

'Yudi Latif, "Iman, Korupsi dan Etos Kerja” dalam Rahmat Hidayat dan Achmad Rifki (Ed), Ibadah Ritual, Ibadah Sosial: Jalan Kebahagiaan Dunia Akhirat (Cet. I; Jakarta: PT. Elex Media Komputindo, 2011), h. 177.

${ }^{2}$ Yudi Latif, "Iman, Korupsi dan Etos Kerja" dalam Rahmat Hidayat dan Achmad Rifki (Ed), Ibadah Ritual, Ibadah Sosial: Jalan Kebahagiaan Dunia Akhirat, h. 178.

${ }^{3}$ Budhy Munawar-Rachman, "Konsep Kerja Islam dan Masalah Alienasi" dalam Nurcholish Madjid et.al., Kehampaan Spiritual Masyarakat Modern: Respon dan Transformasi Nilai-Nilai Islam Menuju Masyarakat Madani, h. 469.

${ }^{4}$ Yudi Latif, "Iman, Korupsi dan Etos Kerja" dalam Rahmat Hidayat dan Achmad Rifki (Ed), Ibadah Ritual, Ibadah Sosial: Jalan Kebahagiaan Dunia Akhirat, h. 179. 
menyuruh umatnya untuk giat bekerja, misalnya firman Allah swt. dalam QS al-Insyirah (94):7,

Terjemahnya:

Maka apabila kamu telah selesai (dari sesuatu urusan), kerjakanlah dengan sungguh-sungguh (urusan) yang lain. ${ }^{5}$

M. Quraish Shihab memahami ayat di atas dengan mengatakan bahwa apabila engkau telah berada dalam keluangan (setelah tadinya engkau sibuk), maka (bersungguh-sungguhlah bekerja) sampai engkau letih, atau tegakkanlah (suatu persoalan baru). Dijelaskan pula bahwa ayat tersebut memberi petunjuk bahwa seseorang harus selalu memiliki kesibukan. Apabila telah berakhir suatu pekerjaan, maka memulai lagi dengan pekerjaan yang lain, sehingga dengan ayat ini seorang muslim tidak mengenal waktu untuk berleha-leha. ${ }^{6}$

Selain dari pada dalil al-qur'an terdapat pula teks-teks dari hadsi Nabi SAW yang memberikan isyarat kepada umat islam agar giat untuk bekerja, seperti pada hadis yang terdapat dalam kitab Sahih al-Bukhari dari Abu Hurairah;

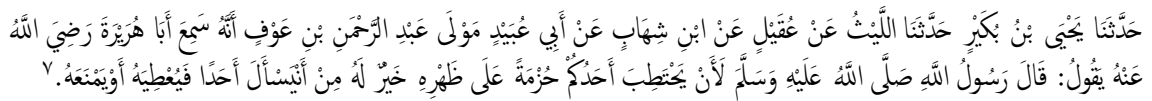

Artinya:

Al-Bukhari berkata: Yahya bin Bukair Telah menceritakan kepada kami, al-Lais telah menceritakan kepada kami dari 'Uqail dari Ibnu Syihab dari Abu 'Ubaid sahayanya 'Abd al-

${ }^{5}$ Departeman Agama RI, al-Qur'an dan Terjemahnya (Cet. I; al-Madinah alMunawwarah: Mujamma' al-Malik Fahd li Tiba'at al-Mushaf, 1418 H), h. 1073.

${ }^{6}$ M. Quraish Shihab, Tafsir Al-Qur'an Al-Karim: Tafsir atas Surah-Surah Pendek Berdasarkan Urutan Turunnya Wahyu (Cet. I; Jakarta: Pustaka Hidayah, 1997), h. 463-464.

${ }^{7}$ Al-Bukhari, Abu 'Abdillah Muhammad bin Isma'il bin Ibrahim Sahih alBukhari, juz. II (Cet. III; Beirut: Dar Ibn Kasir, 1987), h. 730. 
Rahman bin 'Auf bahwa dia mendengar Abu Hurairah ra. berkata; "Sungguh, seorang dari kalian yang memanggul kayu bakar dan dibawa dengan punggungnya lebih baik baginya daripada dia meminta kepada orang lain, baik orang lain itu memberinya atau menolaknya.

Berdasarkan salah satu bukti teks dari hadis tersebut maka penulis akan berupaya membahas tentang etos kerja dalam perspektif hadis Nabi SAW, yang pembahasannya yang akan dibatasi pada bagaimana pemahaman hadis-hadis tentang etos kerja, dilihat dari aspek akidah, ibadah dan akhlak?

\section{Etos kerja dari aspek akidah}

Rasulullah saw. melalui sabdanya telah menjelaskan betapa pentingnya bekerja, sebagaimana dalam sebuah hadis yang diriwayatkan oleh Abu Dawud dari Anas bin Malik sebagai berikut;

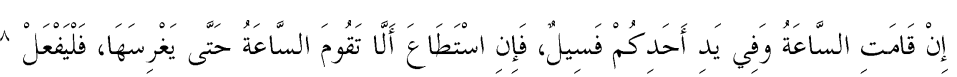

Artinya:

Jika terjadi hari kiamat sedang salah seorang dari kalian mempunyai bibit kurma, jika mampu hendaklah jangan berdiri sampai dia menanamnya.

Hadis di atas memberitakan bahwa sekalipun hari kiamat datang hendaklah seseorang yang ditangannya terdapat biji-bijian atau benih maka hendaklah ia menanamnya jika mampu. Hadis tersebut menunjukkan bahwa betapa pentingnya melakukan sebuah perbuatan baik tanpa menghiraukan hasil dari perbuatannya karena pada dasarnya setiap perbuatan baik ataupun buruk akan ada balasannya sebagaimana yang disebutkan dalam QS al-Zalzalah/100: 7-8;

Terjemahnya;

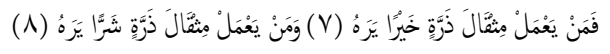

${ }^{8} \mathrm{Abu}$ Dawud Sulaiman ibn Dawud ibn al-Jarud al-Ṭuyalisi, Musnad Abi Dawud. Juz III (Cet. I; Dar Hajar, 1419 H-1444 M.), h. 545. 
Barang siapa yang mengerjakan perbuatan baik walaupun seberat biji zarrah maka ia pasti melihat balasannya. Dan barang siapa yang mengerjakan perbuatan buruk walaupun seberat biji zarrah maka pasti ia akan melihat balasannya.

Al-Salabi dalam kitab tafsirnya al-Kasyif menyampaikan bahwa menurut Ibn 'Abbas tidaklah perbuatan baik dan buruk orang mukmin ataupun kafir kecuali Allah akan memperlihatkan balasannya di dunia, Adapun orang mukmin akan melihat balasan perbuatan baik dan buruknya di dunia, sementara di akhirat perbuatan buruknya akan di ampuni dan kebaikannya akan diberikan balasan (pahala). Sedangkan bagi orang kafir perbuatan baiknya ditolak dan akan disiksa karena perbuatan buruknya. ${ }^{9}$

Penjelasan tersebut menegaskan bahwa perbuatan baik orang mukmin atau kafir akan memperoleh balasan atau hasilnya di dunia, sementara di akhirat orang mukmin akan mendapatkan pahala (balasan) perbuatan baiknya dan orang kafir tidak akan memperoleh balasan atas perbuatan baiknya. Oleh karena itu dalam bekerja orang mukmin harus menanamkan dalam dirinya bahwa segala perbuatan baik akan memperoleh balasan di dunia dan akhirat.

\section{Etos kerja dari aspek ibadah}

Berdasarkan penjelasan hadis-hadis yang berkaitan dengan etos kerja pada tulisan ini, terdapat 2 hadis yang menyinggung tentang ibadah, yaitu hadis tentang segala perbuatan tergantung niat dan hadis tentang do'a agar terhindar dari kefakiran.

a. Segala perbuatan tergantung niat

Mencari rezki dalam islam adalah sebuah keharusan agar dapat menutupi kebutuhan-kebutuhan fisik, sedangkan untuk

${ }^{9}$ Al-Sa'labi, Ahmad bin Muhammad bin Ibrahim, al-Kasyif wa al-Bayan 'an Tafsir al-Qur'an, JuzX (Cet. I; Bairut: Dar Ihya al-Turas al-'Arabi, 1422 H/2002 M), h. 265. 
memperoleh rezki haruslah dengan bekerja, bahkan Allah swt. dalam QS al-Jum'ah/62: 10 memerintahkan kepada orang mukmin untuk bertebabaran di muka bumi untuk mencari rezki. Allah berfirman;

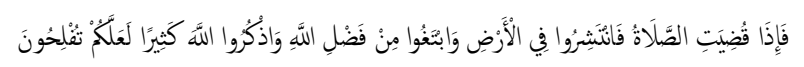

Terjemahnya;

Apabila telah ditunaikan salat maka bertebaranlah kalian di muka bumi dan carilah karunia Allah dan ingatlah Allah sebanyak-banyaknya agar kamu beruntung.

Berdasarkan ayat tersebut maka nampaklah bahwasanya bekerja memiliki kedudukan yang tinggi dalam islam sampai-sampai Allah memerintahkan kepada orang mukmin untuk bertebaran setelah melaksanakan salat. Namun, tujuan seseorang berbeda-beda dalam bekerja, ada yang bertujuan untuk mengumpulkan harta, berpoya-poya, mengejar kebahagian duniawi dan sebagainya. Sehingga mereka mendapatkan tujuannya, tetapi tidak ternilai sebagai ibadah di sisi Allah karena mereka bekerja bukan karena mencari ridha Allah. Rasulullah saw. bersabda;

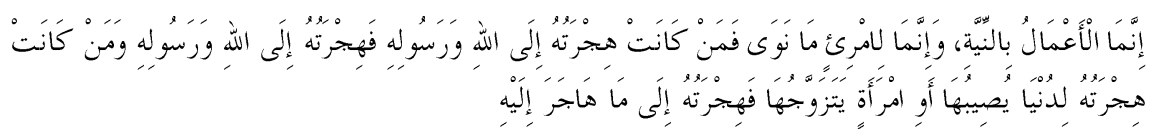

Artinya;

Sesungguhnya amalan itu tergantung dengan niatnya, dan sesungguhnya ia akan mendapatkan sesuatu yang diniatkannya, barangsiapa hijrahnya untuk Allah dan RasulNya, maka hijrahnya untuk Allah dan Rasul-Nya, dan barangsiapa hijrahnya untuk memperoleh dunia atau seorang wanita yang akan dinikahinya, maka hijrahnya sesuai dengan apa yang diniatkannya.

Telah dijelaskan sebelumnya bahwa niat memiliki peranan penting dalam tercapainya hasil dari sebuah pekerjaan dan merupakan pembeda antara ibadah dengan pekerjaan sehari-hari, oleh karena itu dalam bekerja orang mukmin seharusnya berniat 
untuk mencari ridha Allah atau bekerja karena Allah semata agar ternilai sebagai ibadah dan memperoleh hasil pekerjaannya di dunia dan akhirat berupa pahala ibadah bekerja.

b. Berdo'a agar terhindar dari kefakiran

Rasulullah telah mengajarkan kepada umat islam untuk meminta kepada Allah agar terlindungi dari sifat fakir/kekurangan, do'a tersebut ialah;

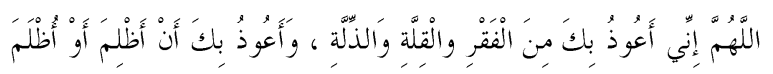

Artinya:

Ya Allah sesungguhnya aku berlindung kepada-Mu dari kefakiran dan kekurangan serta kehinaan dan aku juga berlindung kepada-Mu dari menzhalimi (seseorang) atau dizhalimi

Imam al-Tayyibi berpendapat bahwa fakir mempunyai empat bentuk yaitu: ${ }^{10}$

1. Fakir disebabkan mempunyai kebutuhan yang sangat diperlukan sebagaimana dalam Q.S. Fatir ayat 15:

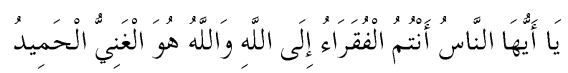

Terjemahnya:

Hai manusia, kamulah yang butuh kepada Allah; dan Allah Dialah yang Maha Kaya (tidak memerlukan sesuatu) lagi Maha Terpuji.

Ayat di atas berlaku secara umum bagi seluruh manusia yang butuh segala sesuatu dari Allah.

2. Fakir disebabkan tidak mempunyai harta sebagaimana dalam Q. S. al-Baqarah ayat 273:

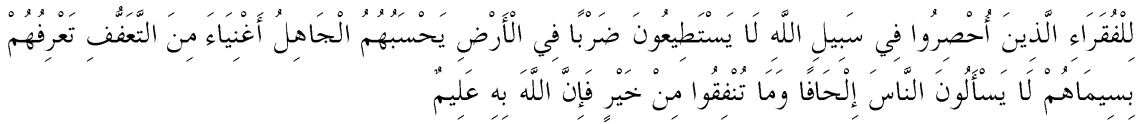

${ }^{10}$ Ali bin Muhammad Abu al-Husain, Marqah al-Mafatih Syarh Masyakkah al-Masabih, Juz IV, (Cet. I; Libanon: Dar al-Fikr, 1422 H/2002 M), h. 1709. 
Terjemahan:

"(Berinfaqlah) kepada orang-orang fakir yang terikat (oleh jihad) di jalan Allah; mereka tidak dapat (berusaha) di bumi; orang yang tidak tahu menyangka mereka orang Kaya karena memelihara diri dari minta-minta.kamu kenal mereka dengan melihat sifat-sifatnya, mereka tidak meminta kepada orang secara mendesak. dan apa saja harta yang baik yang kamu nafkahkan (di jalan Allah), Maka Sesungguhnya Allah Maha Mengatahui.

Ayat tersebut menggambarkan kefakiran seseorang karena tidak memiliki harta dan kemampuan untuk bekerja, oleh karena itu mereka membutuhkan sedekah untuk memenuhi kebutuhannya.

3. Faqir jiwa sebagaimana kebalikan dari hadis Nabi saw. yang terdapat dalam kitab Musnad Ahmad bin Hanbal riwayat Abu Hurairah:

\section{Artinya:}

$$
\text { ليس الغني عن كثرة العرض،ولكن الغني غن النفس"." }
$$

"Kekayaan itu bukanlah diukur dari banyaknya harta benda akan tetapi pada hakekatnya kekayaan itu adalah kekayaan hati".

Hadis tersebut bermakna bahwa kekayaan tidak dilihat dari banyaknya harta benda, tetapi dilihat dari perasaan cukup dengan apa yang dimiliki. Oleh karena itu, orang yang tidak pernah merasa cukup dengan apa yang ia miliki disebut fakir, karena selalu butuh dan menuntut kebutuhan harta oleh ifat tersebut.

4. Faqir kepada Allah sebagaimana kisah nabi Musa yang dikisahkan dalam QS al-Qasas ayat 24

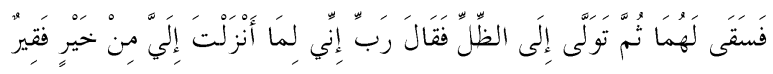

Terjemahnya:

${ }^{11} \mathrm{Abu}$ 'Abdillah Ahmad Ibn Muhammad Ibn Hanbal, Musnad al-Imam Ahmad Ibn Hanbal, Juz VII (Cet I; Kairo: Dar al-Hadis, 1995), hal. 322. 
"Maka Musa memberi minum ternak itu untuk (menolong) keduanya, kemudian Dia kembali ke tempat yang teduh lalu berdoa: "Ya Tuhanku Sesungguhnya aku sangat memerlukan sesuatu kebaikan"12yang Engkau turunkan kepadaku".

Ayat tersebut mengandung makna bahwa nabi Musa a.s butuh kebaikan dari makanan yang Allah turunkan ke bumi.

Fakir yang dimaksud pada hadis tersebut adalah bentuk fakir yang ke-3 yaitu sebuah sifat selalu merasa kurang yang terdapat di dalam hati sehingga dapat membuat seseorang menjadi rakus terhadap harta, tidak pernah merasa puas atas apa yang di miliki bahkan dapat membuat seseorang kufur terhadap nikmat yang Allah berikan dan lupa bersyukur kepada-Nya, oleh karena itu Rasulullah mengajarkan kepada orang mukmin untuk meminta perlindumgan kepada Allah agar terhindar dari sifat tersebut.

\section{Etos kerja dari aspek akhlak}

Berdasarkan penjelasan hadis-hadis yang berkaitan dengan etos kerja pada tulisan ini, terdapat 3 hadis yang menyinggung tentang akhlak, yaitu hadis tentang mencari kayu bakar (motivasi bekerja), tangan di atas lebih baik daripada tangan di bawah (menjaga harga diri) dan makanan terbaik adalah hasil kerja keras sendiri (berwirausaha).

a. Motivasi untuk bekerja

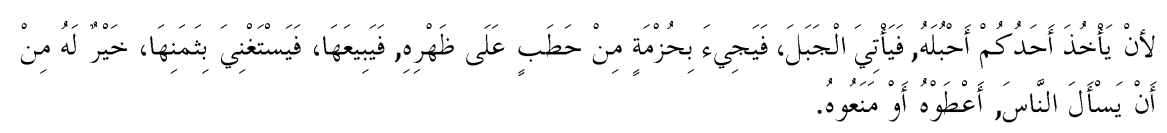

Artinya;

Seorang lelaki yang membawa seutas tali, dia pergi ke gunung, kemudian (kembali) dengan membawa seikat kayu bakar dan menjualnya sehingga dia merasa cukup dengan hasil tersebut adalah lebih baik baginya daripada meminta-

${ }^{12}$ Yang dimaksud dengan Khair (kebaikan) dalam ayat ini menurut sebagian besar ahli tafsir ialah barang sedikit makanan. 
minta kepada manusia baik mereka memberi atau menolaknya."

Hadis di atas merupakan motivasi bagi umat islam dalam bekerja karena pada hadis tersebut menjelaskan bahwa seberat/sesulit apapun pekerjaan selama dilalui dengan cara-cara yang baik, kemudian ia menikmati hasil dari pekerjaan tersebut masih lebih baik daripada hanya meminta dan berharap kepada orang lain. Bahkan Rasulullah saw menyebutkan bahwa Allah lebih menyukai mukmin yang kuat dari pada mukmin yang lemah sebagaimana hadis yang terdapat dalam kitab Sahih Muslim;

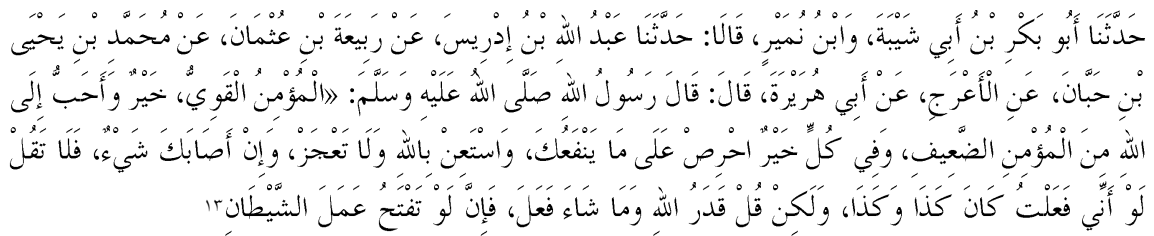

Artinya;

'Orang mukmin yang kuat lebih baik dan lebih dicintai oleh Allah Subhanahu wa Ta 'ala daripada orang mukmin yang lemah. Pada masing-masing memang terdapat kebaikan. Capailah dengan sungguh-sungguh apa yang berguna bagimu, mohonlah pertolongan kepada Allah Azza wa Jalla dan janganlah kamu menjadi orang yang lemah. Apabila kamu tertimpa suatu kemalangan, maka janganlah kamu mengatakan; 'Seandainya tadi saya berbuat begini dan begitu, niscaya tidak akan menjadi begini dan begitu'. Tetapi katakanlah; 'Ini sudah takdir Allah dan apa yang dikehendakiNya pasti akan dilaksanakan-Nya. Karena sesungguhnya ungkapan kata 'law' (seandainya) akan membukakan jalan bagi godaan syetan.

Hadis di atas sejatinya dapat dijadikan oleh orang mukmin sebagai motivasi dalam bekerja agar termasuk orang-orang yang dicintai oleh Allah. Bahkan pada hadis tersebut Rasulullah saw

${ }^{13}$ Muslim bin al-Hajjaj bin al-Qusyairi al-Naisaburi Abu al-Husain, Jami alSahih al-Musamma Sahih Muslim. Juz IV (Beirut: Dar Ihya al-Turas al-'Arabi, t.th.), h. 1987. 
memerintahkan kepada orang mukmin agar bekerja dengan penuh kesungguhan dan mengerahkan seluruh aset, pikir dan dzikirnya untuk mengaktualisasikan atau menampakkan arti dirinya sebagai hamba Allah yang harus menundukkan dunia dan menempatkan dirinya sebagai bagian dari masyarakat yang terbaik (khairu ummah) atau dengan kata lain bahwa hanya dengan bekerjalah manusia memanusiakan dirinya. Kerja adalah suatu cara untuk memenuhi kebutuhan manusia baik kebutuhan fisik, psikologis, maupun sosial. Dengan pekerjaan manusia akan memperoleh kepuasan-kepuasan tertentu yang meliputi pemenuhan kebutuhan fisik dan rasa aman, serta kebutuhan sosial dan kebutuhan ego.

Selain itu, kerja adalah aktivitas yang mendapat dukungan sosial dan individu itu sendiri. Dukungan sosial itu dapat berupa penghargaan masyarakat terhadap aktivitas kerja yang ditekuni. Sedangkan dukungan individu dapat berupa kebutuhan-kebutuhan yang melatar belakangi aktivitas kerja. Seperti kebutuhan untuk aktif, berproduksi, berkreasi, memperoleh pengakuan dari orang lain, memperoleh prestise serta kebutuhan-kebutuhan lainnya. Bekerja merupakan kegiatan pokok dari suatu aktivitas kemanusiaan yang dapat dibagi menjadi sejumlah dimensi, yaitu fisiologis, psikologis, ikatan sosial dan ikatan kelompok, ekonomi, dan dimensi yang lain.

Kerja keras bukan hanya dilakukan pada saat memulai saja, tetapi juga terus dilakukan walaupun sudah berhasil mencapai citacita. Melakukan perbaikan dengan terus menerus, terhadap pekerjaan yang telah lalu, jangan terlena karena keberhasilan. ${ }^{14}$ Jika merujuk pada syari'at Islam, kekayaan dipandang amat penting sebagai sarana untuk dapat menjalankan ketentuan-ketentuannya, dan paling tidak ada dua rukun Islam yang mensyaratkan

${ }^{14}$ Buchari Aima, Ajaran Islam Dalam Bisnis, (Bandung; CV. Alfabeta, 1994), h. 12 
kemampuan ekonomi yang cukup, yaitu untuk melaksanakan kewajiban zakat dan haji.

Secara hakiki bekerja bagi seorang muslim merupakan ibadah sekaligus sebagai bukti pengabdian dan rasa syukurnya untuk mengolah dan memenuhi panggilan Ilahi agar mampu menjadi yang terbaik karena mereka sadar bahwa bumi diciptakan sebagai ujian untuk memeperoleh predikat hamba yang terbaik amalannya. Sebagaimana firman Allah pada QS. al-Kahfi/18: 7:

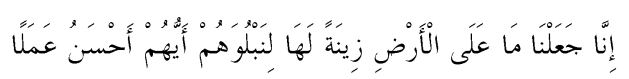

Terjemahnya;

"Sesungguhnya Kami telah menciptakan apa-apa yang ada di bumi sebagai perhiasan baginya, supaya Kami menguji mereka siapakah yang terbaik amalnya"

Toto Tasmara mengatakan bahwa karena kebudayaan kerja islami bertumpu padaAkhlaq al-Karimah, maka umat Islam akan menjadikan akhlak sebagai energi batin yang terus menyala dan mendorong setiap langkah kehidupannya dalam koridor jalan yang lurus. Semangat dirinya adalah min Allah, fi sabil Allah, Ila Allah (dari Allah, dijalan Allah, dan untuk Allah). ${ }^{15}$

Berdasarkan penjelasan-penjelasan di atas maka dapat dipahami bahwa orang mukmin harus memiliki motivasi dalam bekerja, niat yang kuat dalam bekerja dan bekerja sesuai dengan aturan akhlaq al-Karimah, serta menyandarkan pekerjaannya kepada Allah sebagai dorongan untuk memperoleh rezki yang diridhoi-Nya.

b. Menjaga harga diri

Rasulullah saw bersabda;

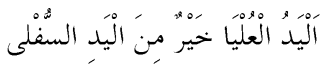

Artinya:

${ }^{15}$ Toto Tasmara, Membudayakan Etos Kerja Islam, (Jakarta; Gema Insani Press, 2002), h. 2 
"Tangan di atas lebih baik daripada tangan yang di bawah

Hadis tersebut secara tekstual menyebutkan bahwa tangan di atas (memberi) lebih baik dari pada tangan di bawa (menerima/meminta). Namun hadis tersebut dapat bermakna menjaga harga diri. Oleh karena itu dapat dilihat bahwa hadis tersebut mengajarkan 2 cara dalam menjaga harga diri, yaitu berusaha memberi dan menjauhkan diri dari meminta-minta.

1. Al-yadu al-'ulya (memberi)

Penggalan hadis tersebut merupakan gambaran bahwa orang yang memberi lebih baik daripada menerima, kata al-yadu al-'ulya sendiri memiliki beberapa makna, yakni menjaga diri, memberi nafkah dan brsedakah. Dengan demikian dapat disimpulkan bahwa hakikat dari kata al-yadu al-'ulya tersebut ialah menjaga harga diri dengan memberi nafkah dan sedekah. Sebagaimana yang telah dijelaskan oleh hadis Rasulullah saw yang terdapat dalam kitab Sahih al-Bukhari yang diriwayatkan dari Musa bin Isma'il dari Wuhaib dari Hisyam dari bapaknya dari Hakim bin Hizam dari Nabi saw bahwa;

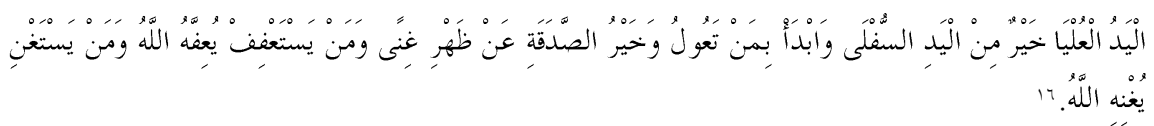

Artinya;

"Tangan yang diatas lebih baik dari pada tangan yang di bawah, maka mulailah untuk orang-orang yang menjadi tanggunganmu dan shadaqah yang paling baik adalah dari orang yang sudah cukup (untuk kebutuhan dirinya). Maka barangsiapa yang berusaha memelihara dirinya, Allah akan memeliharanya dan barangsiapa yang berusaha mencukupkan dirinya maka Allah akan mencukupkannya".

Hadis tersebut mengandung beberapa makna;

a. Pَابْدَا بِمَنْ تَعُولُ

Al-Nawawi menjelaskan bahwa penggalan hadis tersebut mengandung makna mendahulukan nafka dirinya dan keluarganya

${ }^{16} \mathrm{Al}-$ Bukhari, Sahih al-Bukhari, juz. I, h. 441. 
dan mendahulukan kebutuhan dirinya pada perkara syari'at/agama. ${ }^{17}$ Rasûlullâh saw pada hadisnya yang lain telah memerintahkan hal tersebut:

Artinya;

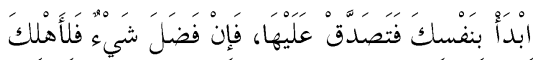

Mulailah dari dirimu, bersedekahlah untuknya, jika ada sisa, maka untuk keluargamu.

Dalam hadits lain juga dikatakan:

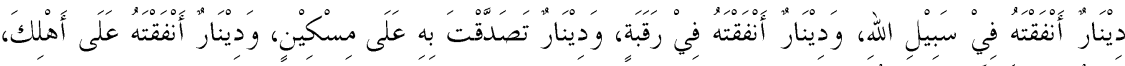

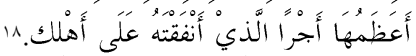

Artinya;

Satu dinar yang engkau infaqkan di jalan Allâh, satu dinar yang engkau infakkan untuk memerdekakan seorang hamba (budak), satu dinar yang engkau infakkan untuk orang miskin, dan satu dinar yang engkau infakkan untuk keluargamu, maka yang lebih besar ganjarannya ialah satu dinar yang engkau infakkan untuk keluargamu.

Potonga hadis di atas menunjukkan bahwa seseorang yang suka memberi atau ingin memberi di anjurkan agar memulai dan memprioritaskan orang yang menjadi tanggungannya, yakni yang wajib ia nafkahi. Menafkahi keluarga lebih utama daripada bersedekah kepada orang miskin, karena menafkahi keluarga merupakan sedekah dan dengan sedekah itu juga dapat menguatkan hubungan kekeluargaan, dan menjaga kesucian diri, maka itulah yang lebih utama. Demikian pula dalam berinfak yang telah di atur oleh syari'at islam, yaitu berinfaq untuk diri sendiri terlebih dahulu lebih utama daripada berinfak untuk selainnya, lalu kepada orang orang yang berada dalam tanggungannya, seperti istri, anak, orang tua ataupun keluarga dekat.

${ }^{17} \mathrm{Al}-N a w a w i$, Mahyi al-Din Yahya bin Syarf Abu Zakariyya, al-Manahij Syarh Sahih Muslim, Juz VII (Cet. II; Bairut: Dar Ihya al-Turas al-'Arabi, 1392 H),.h. 1`25.

${ }^{18}$ Muslim bin al-Hajjaj, Sahih Muslim, Juz II, h. 692. 


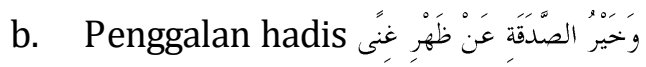

Al-Tayyib Ahmad Hatibah menjelaskan bahwa makna penggalan hadis tersebut ialah sebaik-baik sedekah adalah yang menyisakan kecukukupan, karena manusia kadang-kadang ada yang bersedekah dengan semua hartanya dan setelah bersedekah kemungkinan Allah akan mengujinya sementara ia tidak lagi memiliki harta yang akan menutupi kebutuhannya sehingga ia menyesal. ${ }^{19}$ Berdasarkan penjelasan tesebut maka dapat dipahami bahwa sekalipun seseorang memiliki harta yang banyak dan suka bersedekah, hendaklah ia bersedekah dengan sebahgian dari hartanya saja, karena masih ada kemungkinan Allah akan mengujinya dengan ujian yang membutuhkan harta, sebagaiman firman Allah pada QS al-Baqarah/02; 155:

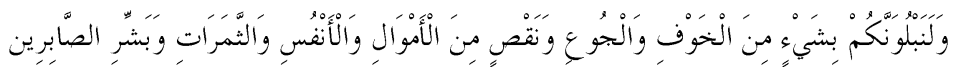

Terjemahnya;

Dan kami pasti akan menguji kamu dengan sedikit ketakutan, kelaparan, kekurangan harta, jiwa dan buah-buahan. Dan sampaikanlah kabar gembira kepada orang-orang yang sabar.

Ayat tersebut menegaskan bahwa Allah akan menguji manusia dengan berbagai hal yang di antaranya berupa kekurangan harta, oleh karena itu orang mukmin tidak boleh mensedekahkan seluruh hartanya.

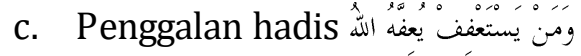

Penggalan hadis tersebut merupakan pernyataan bahwa orang yang memelihara dirinya akan dijaga oleh Allah. Hamzah Muhammad Qasim menjelaskan bahwa makna penggalan hadis tersebut ialah menjauhkan dirinya dari meminta secara berulang maka Allah akan memberinya penjagaan tersebut dan

${ }^{19}$ Al-Tayyib Ahmad bin Hatibah, Syarh Riyad al-Salihin, Juz XXXVII (t.t: Durus al-Sautiyyah, t.th), h. 13. 
menjadikannya sebagai sifat pembawaan baginya yang menetap dalam dirinya sehingga ia memandang meminta-minta sebagai pekerjaan yang hina dan membencinya karena pembawaan tersebut. ${ }^{20}$

Penjelasan tersebut menegaskan bahwa ketika seseorang berusaha unruk menjaga dirinya dari pekerjaan meminta-minta, Allah akan memberikan kepadanya sebuah pembawaan yang akan membantunya untuk menjauhi pekerjaan meminta-minta.

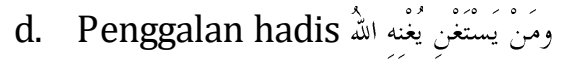

Penggalan hadis tersebut merupakan pernyataan bahwa ketika seseorang telah merasa cukup maka Allah akan memberikan kecukupan kepadanya. Al-Sa'di menjelaskan bahwa penggalan hadis tersebut bermakna orang yang merasa cukup denagan apa yang ada pada genggamannya (miliki) darpada apa yang ada pada genggaman orang lain maka Allah akan memberikan kecukupan kepadanya. Maka barang siapa yang bergantung kepada Allah, menyerahkan kebutuhannya kepada-Nya dan bertawakkal kepada-Nya serta menghilangkan ketergantungan dari makhlu-makhluk-Nya maka tidak ada keraguan bahwa pasti ia akan hidup dengan penuh ketenangan jiwa. ${ }^{21}$

Penjelasan tersebut menegaskan bahwa orang yang merasa cukup dengan apa yang ia miliki akan memperoleh kecukupan dari Allah, sehingga ia hanya bergantung kepada Allah, menyerahkan segala kebutuhannya, bertawakkal dan tidak bergantung kepada makhluq lain oleh karena itu ia akan merasan ketenanga dalam hidup. Pada dasarnya orang mukmin yang selalu merasa cukup dengan apa yang dimiliki merupakan wujud dari bersyukur oleh

${ }^{20}$ Hamzah Muhammad Qasim, Manar al-Qari Syarh Miqtasar Sahih alBukhari, Juz III, h. 43.

${ }^{21} \mathrm{Al}-\mathrm{Sa}$ 'di, 'Abd al-Rahman bin Nasir, Syarh Jawami' al-Akhbar, Juz V, (t.t: Durus al-Mufrigah, t.th), h. 50 . 
karena itu Allah selalu menambahkan apa yang telah ia syukuri, sebagai yang telah Allah firmankan dalam QS Ibrahim/14: 7:

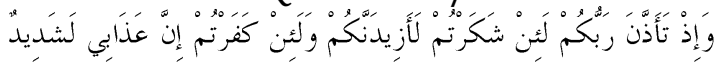

Terjemahnya;

Dan ingatlah ketika Tuhanmu memaklumkan, sesungguhnya jika kamu bersyukur, niscaya aku akan menambahkan (nikmat) kepadamu, tetapi jika kamu mengingkari (nikmat$\mathrm{Ku}$ ), maka pasti azab-Ku sangat pedih.

Ayat di atas menegaskan bahwa ketika orang mukmin bersyukur terhadap nikmat yang ia peroleh dari Allah maka Allah akan membahkan nikmat kepadanya namun jika orang mukmin tidak bersyukur atau mengingkarinya akan mendapatkan siksaan. Demikian pulalah orang mukmin yang merasa cukup terhadap apa yang ia miliki merupakan bentuk kesyukurannya sehingga Allah senantiasa memberika kecukupan rezki kepadanya sehingga ia tidak menggantungkan kebutuhannya kepada selain Allah. Bahkan Rasulullah saw menggolongkan mereka sebagai orang yang beruntung, sebagaimana yang terdapat pada kitab Sahih Muslim;

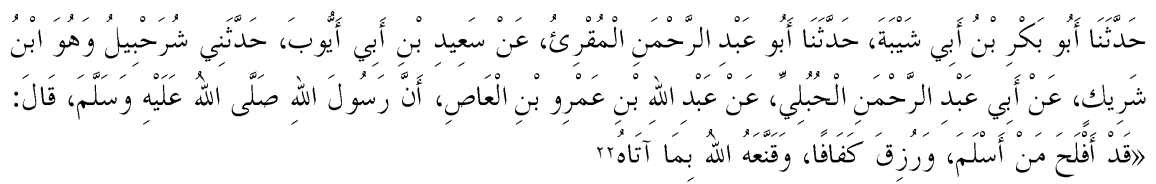

Artinya;

Sungguh beruntung orang yang masuk Islam, diberikan rezeki yang cukup, dan dia merasa puas dengan apa yang Allâh berikan kepadanya.

Berdasarkan penjelasan-penjelasan di atas, maka dapat dipahami bahwa wujud menjaga diri pada penggalan hadis al-yadu al-ùlya orang mukmin menjaga harga diri dengan memberi atau bersedakah ketika memiliki kelebihan harta, berusaha mejaga harga diri dari meminta dan menjauhi ketergantungan kepada orang lain.

2. Al-yadu al-Sufla (meminta)

${ }^{22}$ Muslim bin al-Hajjaj, Sahih Muslim, Juz II, h. 730. 
Al-yadu al-sufla dapat bermakna mengambil, menerima dan meminta, sementara konteks menjaga harga diri yang dimaksud pada hadis tangan di atas lebih baik daripada tangan dibawah ialah menerima hasil dari meminta. Rasulullah saw telah memperingatkan orang mukmin tidak boleh meminta-minta kecuali karena salah satu dari tiga hal yang dibolehkan, hadis tersebut terdapat pada kitab Sahih Muslim yang diriwayatkan dari Yahya bin Yahya dari Hammad bin Sa'id dari Harun bin Riyab dari Kinanah bin Nu'aim dari Qabisah bin Mukhariq yang berkata;

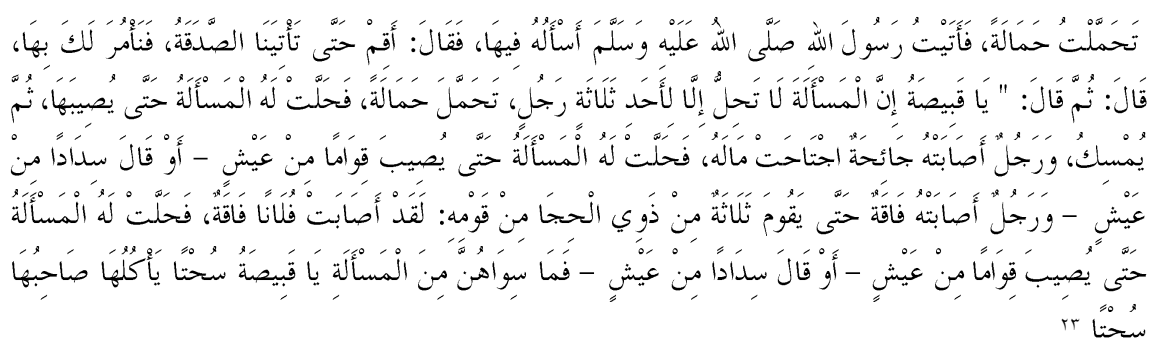

Artinya:

Aku pernah menanggung hutang (untuk mendamaikan dua kabilah yang saling sengketa). Lalu aku datang kepada Rasulullah shallallahu 'alaihi wasallam, meminta bantuan beliau untuk membayarnya. Beliau menjawab: "Tunggulah sampai orang datang mengantarkan zakat, nanti kusuruh menyerahkannya kepadamu." Kemudian beliau melanjutkan sabdanya: "Hai Qabishah, sesungguhnya meminta-minta itu tidak boleh (tidak halal) kecuali untuk tiga golongan. (Satu) orang yang menanggung hutang (gharim, untuk mendamaikan dua orang yang saling bersengketa atau seumpanya).Maka orang itu boleh meminta-minta, sehingga hutangnya lunas. Bila hutangnya telah lunas, maka tidak boleh lagi ia memintameminta. (Dua) orang yang terkena bencana, sehingga harta bendanya musnah.Orang itu boleh meminta-minta sampai dia memperoleh sumber kehidupan yang layak baginya.(Tiga) orang yang ditimpa kemiskinan, (disaksikan atau diketahui oleh tiga orang yang dipercayai bahwa dia memang

${ }^{23}$ Muhammad bin al-Ḥajjaj, Șahih Muslim, Juz II, h. 121. 
miskin).Orang itu boleh meminta-minta, sampai dia memperoleh sumber penghidupan yang layak.Selain tiga golongan itu, haram baginya untuk meminta-minta, dan haram pula baginya memakan hasil meminta-minta itu."

Hadis di atas dengan tegang menyatakan bahwa orang mukmin tidak boleh meminta-minta kecuali salah satu dari 3 hal yang memaksa ia harus meminta yatu; 1. Orang yang menanggung utang untuk mendamaikan dua orang yang bersengketa, 2. Orang yang ditimpa musibah sehingga harta bendanya habis dan 3. Orang yang benar-brnar ditimpa kemiskinan. Maka selain dari tiga hal tersebut haram bagi orang mukmin untuk meminta-minta.

Penjelasan di atas menunjukkan bahwa dalam hal tertentu, orang mukmin dibolehkan untuk meminta jika ditimpa oleh salah satu hal yang telah Rasulullah sebutkan, bahkan Allah dalam Qs. AlDuha ayat 10 berfirman;

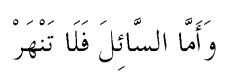

Terjemahnya;

Dan terhadap orang yang meminta-minta, janganlah engkau menghardiknya.

Ayat di atas merupakan larangan kepada orang mukmin untuk menghardik orang mukmin lain yang meminta-minta karena keadaan terpaksa. Sementara bagi orang mukmin yang memintaminta hanya untuk memperbanyak harta, bukan karena kebutuhan disebut seakan-akan hanya meminta bara api, sebagaiman yang diriwayatkan oleh Imam Muslim dalam kitab Sahih-nya;

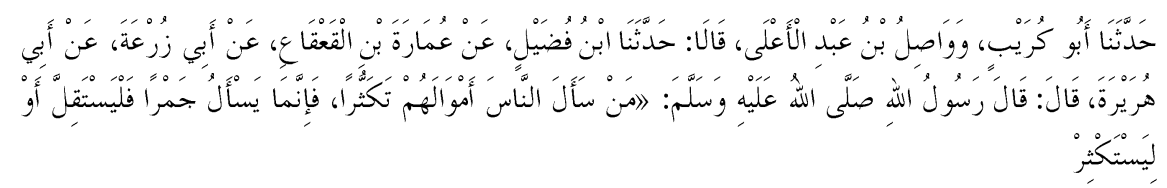

Artinya; 
Barangsiapa meminta harta kepada orang lain untuk memperkaya diri, maka sungguh, ia hanyalah meminta bara api, maka silakan ia meminta sedikit atau banyak.

Hadis di atas merupakan ancaman bagi orang yang memintaminta bukan karena kebutuhan ataupun dalam keadaan terdesak seakan meminta bara api, sedikit ataupun banyak yang ia minta sama saja hukumnya. Oleh karena itu orang mukmin haru menjauh dari perbuatan meminta-minta selain daripada yang diboleh oleh hadis tersebut sebagai bentuk pemeliharaan harga dirinya.

c. Hadis tentang berwirausaha

Rasulullah bersabda

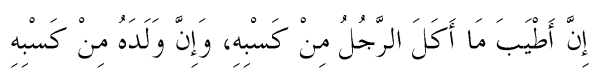

Artinya:

Seseungguhnya yang paling baik adalah apa yang seseorang makan dari kerja kerasnya dan sesungguhnya anaknya merupakan bagian dari kerja kerasnya.

Hadis tersebut menyebutkan bahwa sebaik-baik pekerjaan ialah hasil dari keringat sendiri. Al-Khuli menjelaskan bahwa seseorang yang berusaha untuk memenuhi kebutuhannya dengan cara bekerja keras menggunakan tangannya sendiri, memeras keringat dan energi dari badannya kemudian memakan hasilnya, sudah tentu lebih baik daripada memakan hasil yang bersumber dari peninggalan/warisan, pemberian atas kemurahan seseorang atau sedekah yang diberikan kepadanya karena belas kasihan. Karena usaha seseorang mencari nafkah dengan memeras tenaga, mencucurkan keringat itu akan memberikan kenikmatan sehingga ketika ia memakannya akan terasa lebih enak, dan makanan itu dicerna dengan cepat oleh pencernaan sehingga berguna bagi kesehatan tubuh. ${ }^{24}$

${ }^{24}$ Muhammad 'Abdu al-'Aziz bin 'Ali al-Syazili al-Khuli, al-Adab al-Nabawi, Juz I, (Cet. IV; Dar al-Ma'rifah, 1423H), h. 32. 
Islam senantiasa mengajarkan kepada umatnya agar berusaha untuk memenuhi kebutuhan hidupnya. Tidak dibenarkan bagi seorang muslim berpangku tangan saja atau berdoa mengharap rezeki datang dari langit tanpa mengiringinya dengan usaha. Namun demikian, tidak dibenarkan pula terlalu mengandalkan kemampuan diri sehingga melupakan pertolongan Allah SWT.dan tidak mau berdoa kepada-Nya. ${ }^{25}$ Oleh karena itu usaha dan do'a haruslah mengiringi orang mukmin dalam bekerja.

Islam pada dasarnya telah mengatur segala bentuk perbuatan dengan menjelaskan batasan hukum dari perkara-perkara yang halal maupun haram sebagaimana yang telah disampaikan oleh Rasulullah dalam kitab pada kitab Sahih Muslim yang diriwatkan dari Muhammad bin 'Abdullah dari 'Abdullah bin Numair dari Zakariya dari al-Sya'bi dari al-Nu'man yang mendengar Rasulullah bersabda bahwa;

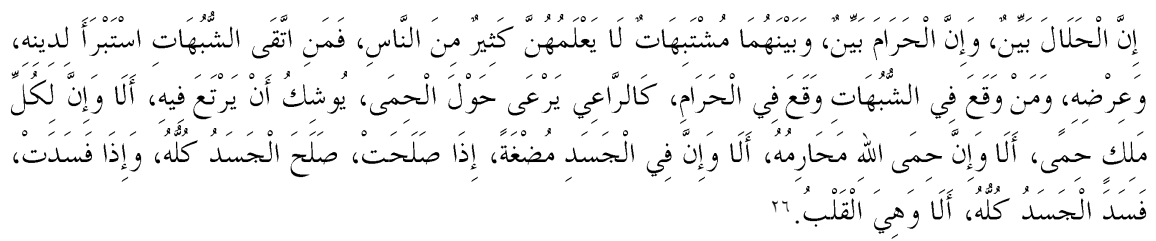

Artinya;

Sesungguhnya yang halal telah nyata (jelas) dan yang haram telah nyata. Dan di antara keduanya ada perkara yang tidak jelas, yang tidak diketahui kebanyakan orang, maka barangsiapa menjaga dirinya dari melakukan perkara yang meragukan, maka selamatlah agama dan harga dirinya, tetapi siapa yang terjatuh dalam perkara syubhat, maka dia terjatuh kepada keharaman. Tak ubahnya seperti gembala yang menggembala di tepi pekarangan, dikhawatirkan ternaknya akan masuk ke dalamnya. Ketahuilah, setiap raja itu memiliki

25 Rachmat Syafe'i. Al-Hadis (Aqidah, Akhlak, Sosial, dan Hukum).(Bandung: CV. Pustaka Setia). H. 114.

${ }^{26}$ Muslim bin al-Hajjaj, Jami al-Sahih al-Musamma Sahih Muslim. Juz III, h. 1219. 
larangan, dan larangan Allah adalah sesuatu yang diharamkannya. Ketahuilah, bahwa dalam setiap tubuh manusia terdapat segumpal daging, jika segumpal daging itu baik maka baik pula seluruh badannya, namun jika segumpal daging tersebut rusak, maka rusaklah seluruh tubuhnya. Ketahuilah, gumpalan darah itu adalah hati.

Hadis tersebut merupakan dalil bahwa persoalan haram dan halal telah jelas batasannya, oleh karena itu hendaklan orang mukmin bekerja dengan cara-cara yang halal, sebagaimana yang telah di cintohkan dalam QS al-Baqarah/02: 275, Allah berfirman;

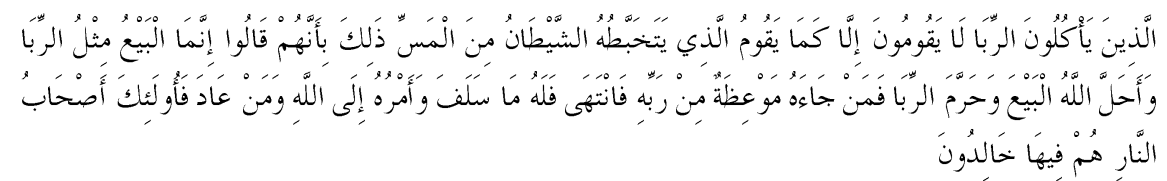

Terjemahnya;

Orang-orang yang memakan riba tidak dapat berdiri melainkan seperti berdirinya seseorang yang kemasukan setan karena gila. Yang demikian karena meraka berkata bahwa jual beli sama dengan riba. Padahal Allah telah menghalalkan jual beli dan mengharamkan riba. Barang siapa yang mendapatkan peringatan dari tuhan-Nya lalu dia berhenti maka apa yang telah diperolehnya dahulu menjadi miliknya dan urusannya (terserah) kepada Allah. Barang siapa yang mengulangi maka mereka itu penghuni neraka, mereka kekal di dalamnya

Ayat di atas menjelaskan tentang jual beli dan mengharamkan riba sebagai batasan kehalalan jual beli, serta menyebutkan kelakuan orang-orang yang menyamakan riba dengan jual beli dan memakan hasilnya seperti orang gila yang kemasukan setan, bahkan di ancam akan dimasukkan kedalam neraka.

Abu Ja'far al-Tabari menjelaskan bahwa maksud jual beli pada ayat tersebut ialah Allah menghalalkan keuntungan dalam perniagaan, pembelian dan penjualan, serta mengharamkan riba, yaitu penambahan jumlah yang ditetapkan pemilik harta terhadap orang yang mengutang/meminjam dalam menangguhkan dan 
memperlambat utangnya. ${ }^{27}$ Oleh karena itu, riba adalah sebuah penambahan jumlah utang dari pemilik harta kepada orang yang mengutang, sehingga akan menambah kesusahan bagi orang yang mengutang, maka dari itu Allah mengharamkannya.

Penjelasan tersebut menggambarkan bahwa dalam bekerja terdapat hasil yang bersifat halal dan haram akan diperoleh seseorang dari pekerjaanya. Oleh karena itu Allah memerintahkan kepada orang beriman untuk memakan dari yang halal dan baik, sebagaimana yang terdapat dala QS al-Baqarah/02: 172, Allah berfirman;

Terjemahnya;

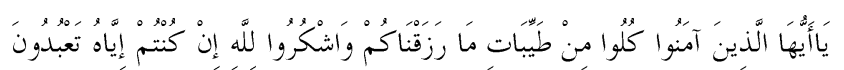

Wahai orang-orang yang beriman! Makanlah dari rezki yang halal lagi baik yang kami berikan kepada kamu dan bersyukurlah kepada Allah, jika kamu hanya menyembah kepada-Nya.

Muhammad Rasyid bin 'Ali bin Rida menjelaskan bahwa lafal perintah pada ayat tersebut menunjukkan kewajiban, bukan kebolehan. Sementara kata الطيبات bermakna usaha yang baik dari yang halal dan mengharuskan ketiadaan seseuatu yang haram dan larangan darinya dalam ketaatan beragama sebagai penyiksaan diri. ${ }^{28}$

Penjelasan di atas menegaskan bahwa Allah swt. menyeru kepada orang mukmin untuk mencari dan memakan rezki dari Allah, akan tetapi rezki tersebut harus bersifat baik dan halal yang diperolah dengan cara yang baik dan halal pula. Oleh karena orang

${ }^{27} \mathrm{Abu}$ Ja'far al-Tabari, Muhammad bin Jarir bin Yazid bin Kasir, Jami' alBayan fi Ta'wil al-Qur'an, Juz VI (Cet. I; t.t: Mu'assasah al-Risalah, 1420 H/2000 M), h. 13.

${ }^{28}$ Muhammad Rasyid bin 'Ali bin Rida bin Muhammad Syams al-Din alHusaini, Tafsir al-Manar, Juz II (Mesir: al-Hai'ah al-Misriyyah al-'Ammah li al-Kitab, 1990 M), h. 77 
mukmin harus memperhatikan hukum dan cara-cara dalam berwirausaha.

Islam mengajarkan kepada umatnya untuk bekerja sesuai dengan kemampuannya. Islam tidak memandang pekerjaan seseorang itu, baik penghasilannya besar maupun kecil yang terpenting yaitu keinginan untuk bekerja keras.Sebaliknya, untuk orang yang kuat fisiknya dan memiliki kecerdasan dalam berpikir tetapi malas untuk bekerja, perbuatan itu sangat dicela oleh Islam, karena umat Islam memiliki kekuatan dan kedudukan yang mulia di sisi Allah swt.

\section{Penutup}

Penelitian penulis terhadap hadis-hadis tentang etos kerja dapat disimpulkan sebagai berikut:

1. Pertama, bahwa hadis yang terkait dengan etos kerja dari aspek akidah ialah hadis tentang anjuran untuk menanam pohon sekalipun hari kiamat telah terjadi. Hadis tersebut memberikan pemahaman bahwa segenting apapun keadaan manusia seharusnya tetap berbuat baik.

2. Kedua, hadis yang berkaitan dengan etos kerja dari aspek ibadah ialah hadis tentang segala perbuatan tergantung dari niat dan berdo'a agar terhindar dari kefakiran. Kedua hadis tersebut memberikan pemahaman bahwa perbuatan dapat dinilai sebagai ibadah jika diniatkan/ditujukan untuk beribadah kepada Allah.

3. Ketiga, bahwa hadis yang terkait dengan etos kerja dari aspek akhlak ialah hadis tentang bekerja dengan mencari kayu bakar, hadis tentang tangan di atas lebih baik daripada tangan di bawa dan hadis tentang berwirausaha. Ketiga hadis tersebut memberikan pemahaman bahwa seberat apapun sebuah pekerjaan masih lebih baik dari pada meminta kepada orang lain. 


\section{DAFT AR PUSTAKA}

Abu Dawud, Sulaiman ibn Dawud ibn al-Jarud al-Ṭuyalisi, Musnad Abi Dawud. Juz 3. Cet. I; Dar Hajar, 1419 H-1444 M..

Abu 'Abdillah, Ahmad Ibn Muhammad Ibn Hanbal. Musnad al-Imam Ahmad Ibn Hanbal. Juz 7. Cet I; Kairo: Dar al-Hadis, 1995.

Abu al-Husain, 'Ali bin Muhammad. Marqah al-Mafatih Syarh Masyakkah al-Masabih. Juz 4. Cet. I; Libanon: Dar al-Fikr, $1422 \mathrm{H} / 2002 \mathrm{M}$.

Abu al-Husain, Muslim bin al-Hajjaj bin al-Qusyairi@ al-Naisaburi. Jami al-Sahih al-Musamma Sahi@h Muslim. Juz 4. Beirut: Dar Ihya al-Turas al-'Arabi, t.th.

Abu Ja'far al-Tabari, Muhammad bin Jarir bin Yazid bin Kasir. Jami' al-Bayan fi Ta'wil al-Qur'an. Juz 6 Cet. I; t.t: Mu'assasah alRisalah, $1420 \mathrm{H} / 2000 \mathrm{M}$.

Aima, Buchari. Ajaran Islam Dalam Bisnis. Bandung; CV. Alfabeta, 1994.

al-Bukhari, Abu 'Abdillah Muhammad bin Isma'il bin Ibrahim. Sahih al-Bukhari. Juz. 1 dan 2. Cet. III; Beirut: Dar Ibn Kasir, 1987.

Departeman Agama RI. al-Qur'an dan Terjemahnya. Cet. I; al-Madinah al-Munawwarah: Mujamma' al-Malik Fahd li Tiba'at alMushaf, $1418 \mathrm{H}$.

al-Husaini, Muhammad Rasyid bin 'Ali bin Rida bin Muhammad Syams al-Din. Tafsir al-Manar. Juz 2. Mesir: al-Hai'ah alMisriyyah al-'Ammah li al-Kitab, 1990 M. 
Latif, Yudi. "Iman, Korupsi dan Etos Kerja” dalam Rahmat Hidayat dan Achmad Rifki (Ed). Ibadah Ritual, Ibadah Sosial: Jalan Kebahagiaan Dunia Akhira..

al-Nawawi, Mahyi al-Din Yahya bin Syarf Abu Zakariyya. al-Manahij Syarh Sahih Muslim, Juz 7. Cet. II; Bairut: Dar Ihya al-Turas al'Arabi, $1392 \mathrm{H}$.

Qasim, Hamzah Muhammad. Manar al-Qari Syarh Miqtasar Sahih alBukhari. Juz 3. Damasyq: Maktabah Dar al-Bayan, 1410 $\mathrm{H} / / 1990 \mathrm{M}$.

al-Sa'di, 'Abd al-Rahman bin Nasir. Syarh Jawami' al-Akhbar. Juz 5. t.t: Durus al-Mufrigah, t.th.

al-Sa'labi, Ahmad bin Muhammad bin Ibrahim. al-Kasyif wa al-Bayan 'an Tafsir al-Qur'an. Juz 10. Cet. I; Bairut: Dar Ihya al-Turas al'Arabi, $1422 \mathrm{H} / 2002 \mathrm{M}$.

Shihab, M. Quraish. Tafsir Al-Qur'an Al-Karim: Tafsir atas Surah-Surah Pendek Berdasarkan Urutan Turunnya Wahyu. Cet. I; Jakarta: Pustaka Hidayah, 1997.

Syafe'i, Rachmat. Al-Hadis (Aqidah, Akhlak, Sosial, dan Hukum). Bandung: CV. Pustaka Setia.

al-Syazili al-Khuli, Muhammad 'Abdu al-'Aziz bin 'Ali. al-Adab alNabawi. Juz 1. Cet. IV; Dar al-Ma'rifah, 1423H.

Tasmara, Toto. Membudayakan Etos Kerja Islam. Jakarta; Gema Insani Press, 2002.

al-Tayyib, Ahmad bin Hatibah. Syarh Riyad al-Salihin. Juz 37. t.t: Durus al-Sautiyyah, t.th. 